\title{
Characterization of near-highway submicron aerosols in New York City with a high-resolution aerosol mass spectrometer
}

\author{
Y. L. Sun ${ }^{1}$, Q. Zhang ${ }^{2}$, J. J. Schwab ${ }^{3}$, W.-N. Chen ${ }^{4}$, M.-S. Bae ${ }^{5}$, H.-M. Hung ${ }^{6}$, Y.-C. Lin $^{4}$, N. L. Ng ${ }^{7}{ }^{*}$, J. Jayne ${ }^{7}$, \\ P. Massoli ${ }^{7}$, L. R. Williams ${ }^{7}$, and K. L. Demerjian ${ }^{3}$ \\ ${ }^{1}$ State Key Laboratory of Atmospheric Boundary Layer Physics and Atmospheric Chemistry, \\ Institute of Atmospheric Physics, Chinese Academy of Sciences, Beijing, China \\ ${ }^{2}$ Department of Environmental Toxicology, University of California, Davis, California, USA \\ ${ }^{3}$ Atmospheric Sciences Research Center, State University of New York at Albany, Albany, New York, USA \\ ${ }^{4}$ Research Center for Environmental Changes, Academia Sinica, Taipei, Taiwan \\ ${ }^{5}$ Environmental Engineering Department, Mokpo National University, South of Korea \\ ${ }^{6}$ Department of Atmospheric Sciences, National Taiwan University, Taipei, Taiwan \\ ${ }^{7}$ Aerodyne Research, Inc., Billerica, Massachusetts, USA \\ *currently at: School of Chemical and Biomolecular Engineering and School of Earth and Atmospheric Sciences, \\ Georgia Institute of Technology, Atlanta, Georgia, USA
}

Correspondence to: Y. L. Sun (sunyele@mail.iap.ac.cn), Q. Zhang (dkwzhang@ucdavis.edu)

Received: 19 September 2011 - Published in Atmos. Chem. Phys. Discuss.: 16 November 2011

Revised: 9 February 2012 - Accepted: 16 February 2012 - Published: 29 February 2012

\begin{abstract}
Knowledge of the variations of mass concentration, chemical composition and size distributions of submicron aerosols near roadways is of importance for reducing exposure assessment uncertainties in health effects studies. The goal of this study is to deploy and evaluate an Atmospheric Sciences Research Center-Mobile Laboratory (ASRC-ML), equipped with a suite of rapid response instruments for characterization of traffic plumes, adjacent to the Long Island Expressway (LIE) - a high-traffic highway in the New York City Metropolitan Area. In total, four measurement periods, two in the morning and two in the evening were conducted at a location approximately $30 \mathrm{~m}$ south of the LIE. The mass concentrations and size distributions of non-refractory submicron aerosol $\left(\mathrm{NR}-\mathrm{PM}_{1}\right)$ species were measured in situ at a time resolution of 1 min by an Aerodyne High-Resolution Time-of-Flight Aerosol Mass Spectrometer, along with rapid measurements (down to $1 \mathrm{~Hz}$ ) of gaseous pollutants (e.g. $\mathrm{HCHO}, \mathrm{NO}_{2}, \mathrm{NO}, \mathrm{O}_{3}$, and $\mathrm{CO}_{2}$, etc.), black carbon (BC), and particle number concentrations and size distributions. Particulate organics varied dramatically during periods with high traffic influences from the nearby roadway. The variations were mainly observed in the hydrocarbon-like organic aerosol (HOA), a surrogate for primary OA from vehicle emissions. The inorganic species
\end{abstract}

(sulfate, ammonium, and nitrate) and oxygenated OA (OOA) showed much smoother variations indicating minor impacts from traffic emissions. The concentration and chemical composition of NR-PM 1 also varied differently on different days depending on meteorology, traffic intensity and vehicle types. Overall, organics dominated the traffic-related NR$\mathrm{PM}_{1}$ composition ( $>60 \%$ ) with HOA accounting for a major fraction of OA. The traffic-influenced organics showed two distinct modes in mass-weighted size distributions, peaking at $\sim 120 \mathrm{~nm}$ and $500 \mathrm{~nm}$ (vacuum aerodynamic diameter, $D_{\mathrm{va}}$ ), respectively. OOA and inorganic species appear to be internally mixed in the accumulation mode peaking at $\sim 500$ $600 \mathrm{~nm}$. The enhancement of organics in traffic emissions mainly occurred at ultrafine mode dominated by HOA, with little relation to the OOA-dominated accumulation mode. From Fast Mobility Particle Sizer (FMPS) measurements, a large increase in number concentration at $\sim 10 \mathrm{~nm}$ (mobility number mean diameter, $D_{\mathrm{m}}$ ) was also found due to traffic influence; though these particles typically contribute a minor fraction of total particle mass. The observed rapid variations of aerosol chemistry and microphysics may have significant implications for near-highway air pollution characterization and exposure assessments. 


\section{Introduction}

On-road vehicle emissions constitute a major source of ultrafine particle pollution and gaseous pollutants (e.g. $\mathrm{CO}, \mathrm{CO}_{2}$, $\mathrm{NO}_{\mathrm{x}}$, and volatile organic compounds (VOCs)) in urban environments (Rogge et al., 1993; Kirchstetter et al., 1999; Zhu et al., 2002a; Canagaratna et al., 2004; Kolb et al., 2004; Zavala et al., 2006; Thornhill et al., 2010). In particular, the number concentrations of ultrafine particles (UFP) from vehicle emissions have been found to account for a major fraction of total number concentrations though they might contribute a small fraction of total volume and mass (Zhu et al., 2002b; Ban-Weiss et al., 2010). Growing evidence shows that people living or otherwise spending substantial time within $\sim 300 \mathrm{~m}$ of highways are exposed to these pollutants more than persons living a greater distance (Massoli et al., 2012). Exposure to the traffic-related air pollutants is associated with the adverse health effects including the prevalence of asthma and chronic obstructive pulmonary disease (COPD) diagnosis, reduced lung function in children, and potential cardiac and pulmonary mortality (Brunekreef et al., 1997; Brugge et al., 2007; Lindgren et al., 2009; Pope et al., 2009). Studies also suggest that the UFP measurements should be conducted in the vicinity of freeway for exposure experiments since UFP number concentration measured at $300 \mathrm{~m}$ downwind from the freeway was indistinguishable from upwind background concentration (Zhu et al., 2002a).

The pollutant levels and aerosol properties vary rapidly as a function of traffic type, traffic flow, meteorology, atmospheric mixing conditions and chemical reactions over short distances near highways. The high variability of nearhighway pollution levels remains a challenge for exposure assessment. In order to capture the rapid changes, mobile laboratories equipped with fast response systems (usually $1 \mathrm{~s}$ ) are often deployed to measure gaseous and particulate pollutants (Canagaratna et al., 2004; Kolb et al., 2004; Herndon et al., 2005; Zavala et al., 2009; Canagaratna et al., 2010; Thornhill et al., 2010). The roadside stationary measurements, chase studies, and fleet average sampling with different driving modes have been conducted to investigate the variability of gases and particle emission ratios (Zavala et al., 2009). A recent study combining the fast on-road measurements of vehicle emissions and positive matrix factorization (PMF) receptor modeling within the Mexico City Metropoli$\tan$ Area (MCMA) was able to distinguish gasoline from diesel emission exhaust (Thornhill et al., 2010). Gasolinepowered vehicles were found to contribute mostly to $\mathrm{CO}$, aromatic and carbonyl species, and ammonia, but a small fraction of $\mathrm{PM}_{2.5}$ and $\mathrm{BC}$ from the total vehicular emissions.

Most previous roadside measurements have been focused on particle number concentration and gaseous species (Morawska et al., 2008; Klems et al., 2010, 2011). Measurements of particle number concentration and numberweighted size distributions downwind of a freeway in Los Angeles showed three distinct ultrafine modes with geo- metric mean diameters of 13,27 , and $65 \mathrm{~nm}$, respectively, within a distance of $30 \mathrm{~m}$ (Zhu et al., 2002b). The number distributions rapidly evolved to larger sizes within 30$90 \mathrm{~m}$ downwind of freeways due to condensation and coagulation. Particle composition in vehicle exhausts may also change dramatically because of size evolution (Zhang et al., 2004). The concentrations of primary emission tracers $\mathrm{CO}, \mathrm{BC}$, and hydrocarbon-like organic aerosol (HOA) also tracked the exponential decrease of particle number concentrations as the distance from the freeway increased (Zhu et al., 2002a; Canagaratna et al., 2010). Similarly, Roorda-Knape et al. (1998) observed the curvilinear decrease of black smoke and $\mathrm{NO}_{2}$ with distance from the motorway depending on wind direction and traffic intensity.

Despite extensive measurements of on-road vehicle emissions, investigations of particle composition are rather limited. Since particle composition is a factor determining particle toxicity, there is a need for characterization of fine particle chemistry in different environments. The measurements of elemental composition near a busy Southern California freeway found elevated concentrations of toxic trace metals (e.g. $\mathrm{Sb}, \mathrm{Cu}, \mathrm{Ba}$ etc.) in PM with aerodynamic diameter smaller than $0.18 \mu \mathrm{m}$ from the vehicles emissions (Ntziachristos et al., 2007). The enrichments of primary traffic emissions including $\mathrm{BC}$ and the toxic metals listed above were also observed while comparing particles collected simultaneously at urban background, traffic and heavy traffic locations (Amato et al., 2011). In contrast, secondary species such as sulfate and ammonium did not show consistent enrichments due to their low vehicle emissions.

The aerosol mass spectrometer (AMS) (Jayne et al., 2000; Jimenez et al., 2003; Drewnick et al., 2005; DeCarlo et al., 2006) allows us to measure non-refractory submicron aerosol $\left(\mathrm{NR}-\mathrm{PM}_{1}\right)$ species (organics, sulfate, nitrate, ammonium, and chloride) with time resolution from seconds to minutes. A vehicle chasing study involving a QuadrupoleAMS deployed inside the Aerodyne mobile laboratory found that aerosol particles from diesel emissions show very similar spectral patterns to that of lubricating oil, and that their massweighted size distributions peak at $\sim 90 \mathrm{~nm}$ in vacuum aerodynamic diameters $\left(D_{\text {va }}\right)$ (Canagaratna et al., 2004). Chemical composition measurements of individual ambient spikes during morning rush hours by a nano-aerosol mass spectrometer showed low $\mathrm{O} / \mathrm{C}$ ratios (generally $<0.5$ ), consistent with their primary characteristics (Zordan et al., 2008). Durant et al. (2010) observed a similar downwind profile of organics to particle number concentration and NO with the highest concentration at $34 \mathrm{~m}$ and then a decrease of $\sim 2$ times within $100-250 \mathrm{~m}$ from the highway. Nitrate and sulfate, however, showed little spatial variation with distance from the highway due to their minor contributions from vehicle emissions (Canagaratna et al., 2010).

The relatively newer version of AMS, i.e. High Resolution Time-of-Flight Aerosol Mass Spectrometer (HRAMS) allows resolving most ion fragments below $\mathrm{m} / z<100$ 
(DeCarlo et al., 2006) and determining the elemental composition $(\mathrm{C}, \mathrm{H}, \mathrm{O}$, and $\mathrm{N}$ ) of organic aerosol (OA) (Aiken et al., 2008). In addition, Positive Matrix Factorization (PMF) analysis of high resolution mass spectra can further deconvolve OA into different components corresponding to different sources and properties and playing different roles in atmospheric chemistry (Ulbrich et al., 2009; Zhang et al., 2011).

Knowledge of particle composition and size distributions, and the causes of their variations near roadway, is of importance for exposure assessment in health studies. Given that pollutants from vehicle emissions may vary significantly in a short time near highways throughout the day, there is a need for multiple roadside measurements of gaseous and particle pollutants at different times and on different days to understand these changes. In the present work, we conducted four roadside measurements, i.e. two in the morning and two in the evening, from a mobile laboratory equipped with a suite of fast response instruments during the summer 2009 Field Intensive Study at Queens College in New York (Sun et al., 2011b; Lin et al., 2012). The objective of our study is to characterize the variations of mass concentrations and chemical composition of NR-PM 1 species, size distributions of NR$\mathrm{PM}_{1}$ species and $\mathrm{OA}$ components, and oxidation states of OA near a highway in different days.

\section{Methods}

\subsection{Sampling site and measurements}

The roadside measurements were conducted at the parking Lot 15 on the campus of Queens College (Fig. 1, site C) with the state-of-the-art Atmospheric Sciences Research CenterMobile Laboratory (ASRC-ML). The ASRC-ML was built upon a 2007 diesel powered Dodge 2500 Sprinter Van equipped with catalytic diesel filter trap emission control. During the roadside measurements, all the instruments were powered alternatively between a $4 \mathrm{~kW}$ gasoline generator and rechargeable $\mathrm{Li}$ ion batteries. A more detailed description of the ASRC-ML has been given in Lin et al. (2012). The ASRC-ML was situated $\sim 30 \mathrm{~m}$ south of the Long Island Expressway (LIE, I-495), one of the busiest high-traffic highways in the NYC metropolitan area, and $\sim 6 \mathrm{~m}$ from the Horace Harding Expressway (HHE), the frontage road of the LIE. The LIE has three westbound lanes and three eastbound lanes with an additional lane exiting the LIE to the HHE. The Kissena Blvd with three northbound lanes and three southbound lanes is approximately $200 \mathrm{~m}$ east of our sampling site. Another high traffic road, Main Street (6 lanes in total), is approximately $600 \mathrm{~m}$ west of the sampling site. Additionally, an MTA bus stop is located approximately $2 \mathrm{~m}$ north of ASRC-ML. Two buses, i.e. Q88 and Q74, stop at the sampling site for $\sim 1 \mathrm{~min}$ every $\sim 7-15 \mathrm{~min}$ and $\sim 15-20 \mathrm{~min}$, respectively. The earliest daily arrival of Q88 and Q74 at the

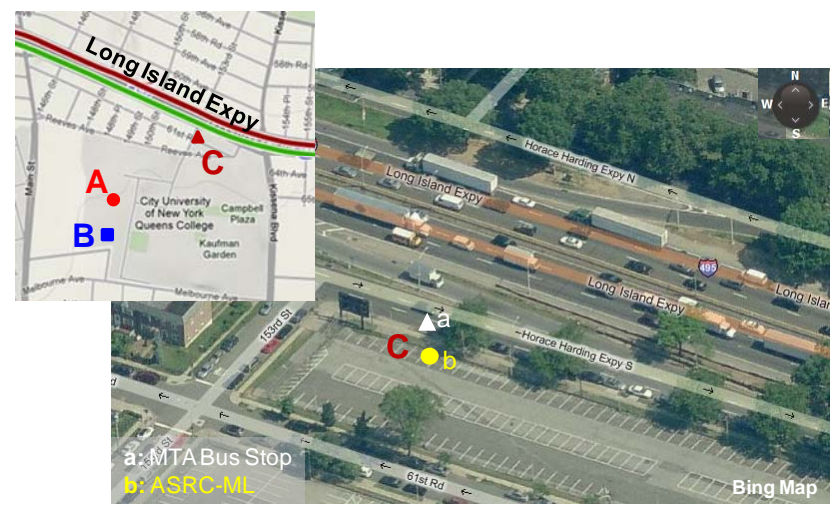

Fig. 1. Map of sampling sites of (A) DEC ambient monitoring station, (B) Parking Lot 6, and (C) Parking Lot 15. An MTA bus stop (a) is $\sim 2$ m north of ASRC-ML (b).

sampling site is $\sim 06: 14$ a.m. and 07:23 a.m. respectively. In total, four measurement periods, two in the morning (03:4108:49 a.m., 28 July; 04:24-10:06 a.m., 30 July) and two in the evening (02:50-05:12 p.m., 27 July; 05:09-10:00 p.m., 1 August), were conducted during this study. Except for the four roadside experiments, the ASRC-ML was situated at parking Lot 6 (Fig. 1, site B) for routine measurements of aerosols and gaseous species from 13 July-3 August, 2009 (Sun et al., 2011a, b). It should be noted that an AerodyneML (Kolb et al., 2004) was deployed in parallel to the ASRC$\mathrm{ML}$ in the morning of 28 July with a focus on characterizing the concentration gradients of aerosols and gaseous species in the vicinity of the LIE and adjacent residential communities to improve our understanding of population exposures (Massoli et al., 2012).

Size-resolved NR-PM 1 species (organics, sulfate, nitrate, ammonium, and chloride) were measured in-situ by an Aerodyne HR-AMS that was operated inside the ASRC-ML (Sun et al., 2011b). In order to capture the fast variations of aerosol species, the HR-AMS was operated under the masssensitive V-mode and the high mass resolution $(\sim 6000) \mathrm{W}-$ mode alternatively every $1 \mathrm{~min}$. Under V-mode operation, the AMS cycled through the mass spectrum (MS) mode and the particle time-of-flight (PToF) mode every $30 \mathrm{~s}$. The parallel measurements inside ASRC-ML include absorption coefficient $\left(B_{\text {abs }}\right)$ by a DMT single-wavelength $(781 \mathrm{~nm})$ Photoacoustic Soot Spectrometer (PASS-1), formaldehyde (HCHO) and $\mathrm{NO}_{2}$ by an Aerodyne Quantum Cascade Laser (QCL) Spectrometer, $\mathrm{CO}_{2}$ and $\mathrm{H}_{2} \mathrm{O}$ by a $\mathrm{Li}-\mathrm{COR} \mathrm{CO}_{2}$ analyzer, trace gases of $\mathrm{O}_{3}, \mathrm{NO}$, and $\mathrm{NO}_{2}$ by $2 \mathrm{~B}$ technologies analyzers, and volatile organic compounds (VOCs) by a BTEX analyzer, aerosol number concentrations by a water-based condensation particle counter (WCPC, TSI 3781) and sizeresolved number concentrations by a TSI Fast Mobility Particle Sizer (FMPS, Model 3091, 5.6-560 nm). All the measurements were performed at fast time resolutions from $1 \mathrm{~min}$ down to $1 \mathrm{~Hz}$. However, some collocated data were not 
available due to the malfunction of the instruments or the non-operation of some instruments because of limited power supply. Collocated measurements of aerosols and gaseous species were also conducted in New York State Department of Environmental Conservation (DEC) Air Monitoring Building (Fig. 1, site A). A key instrument deployed at this site is an Aerosol Chemical Speciation Monitor (ACSM) recently developed by Aerodyne Research Inc. for long-term routine measurements of mass concentrations and chemical composition of ambient aerosols with low cost and maintenance (Ng et al., 2011). The non-refractory aerosol species were measured in-situ at a time resolution of $30 \mathrm{~min}$ from 16 July to 9 September 2009. In addition, the meteorological data including wind direction, wind speed, relative humidity, and temperature measured at the DEC building $(\sim 5 \mathrm{~m}$ above ground, site A) were used as a reference since the synchronous measurement of meteorology at Site C (Lot 15) was not available. Note that the meteorology data, especially wind direction and wind speed might be different considering the different sampling heights and surrounding environments at the two sites. Detailed descriptions of other collocated measurements are given in Sun et al. (2011b) and Lin et al. (2012).

All the data in this study are reported at ambient temperature and pressure conditions in Eastern Standard Time (EST), which equals Coordinated Universal Time (UTC) minus $5 \mathrm{~h}$ or local Time (i.e. East Daylight Time - EDT) minus $1 \mathrm{~h}$.

\subsection{AMS data analysis}

The aerosol mass spectrometry data were analyzed for the mass concentrations and size distributions with the standard AMS data analysis software (SQUIRREL v1.51, Sueper, 2011) and the ion-speciated composition and elemental composition i.e. oxygen-to-carbon $(\mathrm{O} / \mathrm{C})$, hydrogento-carbon $(\mathrm{H} / \mathrm{C})$, nitrogen-to-carbon $(\mathrm{N} / \mathrm{C})$, and organic mass-to-organic carbon $(\mathrm{OM} / \mathrm{OC})$ ratios with the high resolution data analysis software (PIKA, v1.10) and APES (v 1.04A) (http://cires.colorado.edu/jimenez-group/ ToFAMSResources/ToFSoftware/index.html), respectively. The same data analysis procedures have been detailed in Sun et al. (2011b).

We applied positive matrix factorization (PMF) analysis to the high resolution mass spectra (HRMS) acquired near the roadway. The mass spectral and error matrices $(m / z<120)$ were prepared following the procedures described in DeCarlo et al. (2010). The mass spectral datasets from four experiments were combined into one single dataset. The PMF2.exe algorithm (v 4.2) in robust mode (Paatero and Tapper, 1994) was run on the combined dataset to force the retrieved mass spectral profiles to be identical for all four experiments. The PMF2 solutions were then evaluated with an Igor Pro-based PMF Evaluation Tool (PET, v 2.04) (U1brich et al., 2009) following the procedures outlined in Table 1 of Zhang et al. (2011). In addition, the combined dataset was also analyzed with PMF by excluding the data from 27 July when ambient aerosol particles were contaminated by the silicone from the ASRC-ML generator exhaust, and similar results were found. Four OA components were identified including a hydrocarbon-like OA (HOA) that represents primary OA from incomplete fossil fuel combustion given its low $\mathrm{O} / \mathrm{C}$ ratio $(\mathrm{O} / \mathrm{C}=0.08)$ and good correlations with combustion tracers such as $\mathrm{NO}_{\mathrm{x}}$ and $\mathrm{BC}$ (Zhang et al., 2005a; Aiken et al., 2009; Sun et al., 2011b), a regional, oxidized low-volatility oxygenated OA $(\mathrm{LV}-\mathrm{OOA}, \mathrm{O} / \mathrm{C}=0.49)$ that correlates with sulfate, a less photo-chemically aged semi-volatile OOA $(\mathrm{SV}-\mathrm{OOA}, \mathrm{O} / \mathrm{C}=0.34)$ that correlates with nitrate and chloride, and a similar nitrogen-enriched $\mathrm{OA}$ $(\mathrm{NOA})$ characterized by higher N/C ratio $(=0.08)$ than other OA components. Increasing the number of factors led to a further split of SV-OOA into two subtypes of OOA rather than the identification of cooking-related OA (COA) that was observed at Lot 6 (Sun et al., 2011b), indicating that COA accounted for a minor fraction of OA during the four roadside measurements.

A tracer $m / z$-based method was used to derive the size distributions of HOA and OOA in this study. $m / z 44$ (mainly $\mathrm{CO}_{2}^{+}$) that shows tight correlation with OOA (Zhang et al., $2005 \mathrm{a}, 2005 \mathrm{c}$ ) is often used as a tracer for OOA. The size distribution of OOA is thus derived by normalizing the integrated signals of $m / z 44$ between $30-1500 \mathrm{~nm}$ to the OOA concentrations (Zhang et al., 2005c). For Quadrupole-AMS measurements, the size distribution of HOA is derived from $\mathrm{m} / \mathrm{z} 57$ after subtracting its contribution in OOA (Zhang et al., 2005c). The HRMS show that $m / z, 57$ at urban sites in summer mainly constitutes a hydrocarbon ion $\left(\mathrm{C}_{4} \mathrm{H}_{9}^{+}\right)$and an oxygenated ion $\left(\mathrm{C}_{3} \mathrm{H}_{5} \mathrm{O}^{+}\right)$(Sun et al., 2011b). While $\mathrm{C}_{4} \mathrm{H}_{9}^{+}$ tightly correlates with $\mathrm{HOA}, \mathrm{C}_{3} \mathrm{H}_{5} \mathrm{O}^{+}$shows good correlation with $m / z 44$ (Aiken et al., 2009; Sun et al., 2011b), indicating that $\mathrm{C}_{3} \mathrm{H}_{5} \mathrm{O}^{+}$is primarily OOA and $\mathrm{C}_{4} \mathrm{H}_{9}^{+}$is a better tracer for $\mathrm{HOA}$ in comparison to the total $\mathrm{m} / z 57$ signal which includes contributions from both $\mathrm{C}_{4} \mathrm{H}_{9}^{+}$and $\mathrm{C}_{3} \mathrm{H}_{5} \mathrm{O}^{+}$. Thus the size distribution of $\mathrm{HOA}$ was derived using that of $m / z 57$ by subtracting the contribution of $\mathrm{C}_{3} \mathrm{H}_{5} \mathrm{O}^{+}$, the size distribution of which was assumed to be the same as $m / z 44$. The subtracted signals between $30-1500 \mathrm{~nm}$ were then normalized to the corresponding HOA concentrations. This method is found to show similar results to those derived from the tracer $m / z$ based method reported by Zhang et al. $(2005 c)$.

\section{Results and discussion}

\subsection{Mass concentration and chemical composition}

Figure 2 shows the time series of mass concentrations of NR$\mathrm{PM}_{1}$ species and OA components and meteorological variables during roadside measurements, and Fig. 3 presents the average composition for each experiment. Aerosol particles 


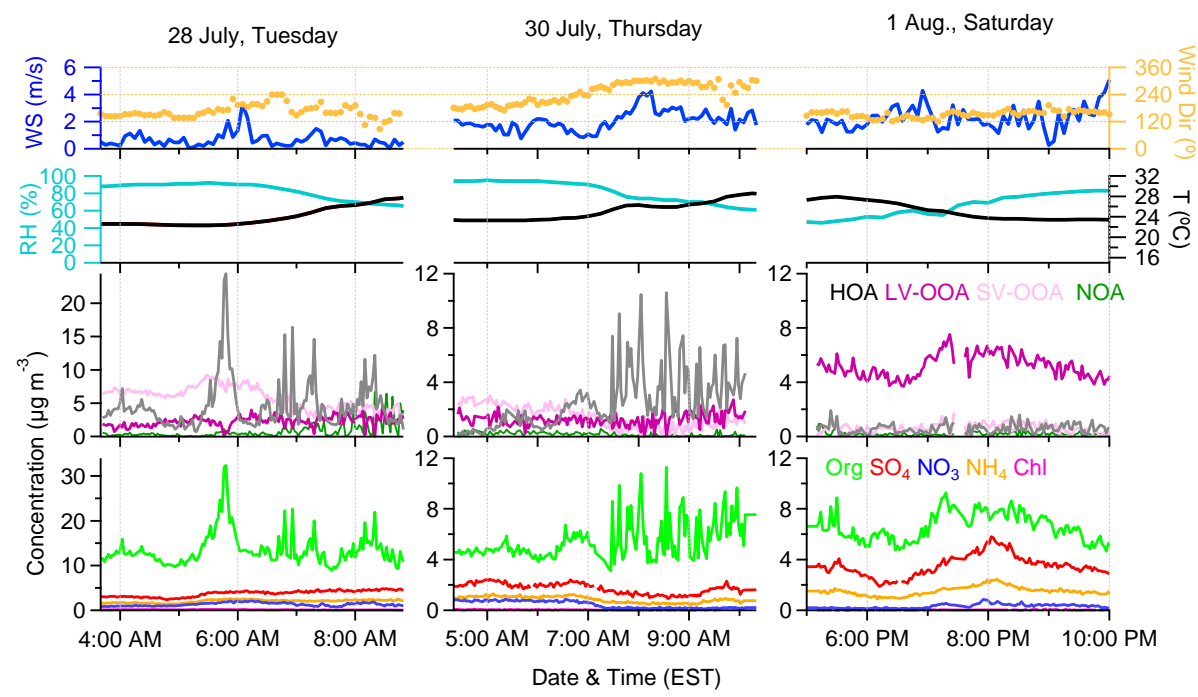

Fig. 2. Time series of mass concentrations of NR-PM 1 species (organics, sulfate, nitrate, ammonium, and chloride), OA components (LVOOA, SV-OOA, HOA, and NOA) and meteorology during three roadside measurements. Note that the meteorological data was collected from the campus site where wind profile might be different from that at the roadside site.

(a) $\operatorname{Org} \mathrm{SO}_{4} \mathrm{NH}_{4} \mathrm{NO}_{3} \mathrm{Chl}$

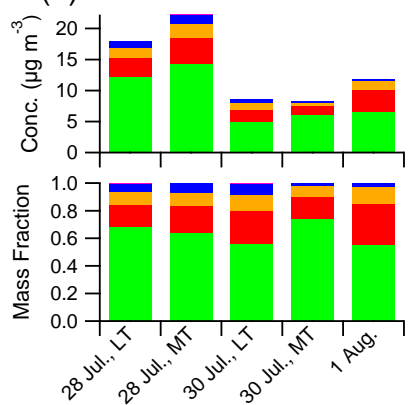

(b) $\stackrel{-O-O O A}{-O / C}$ SV O A HOA NOA

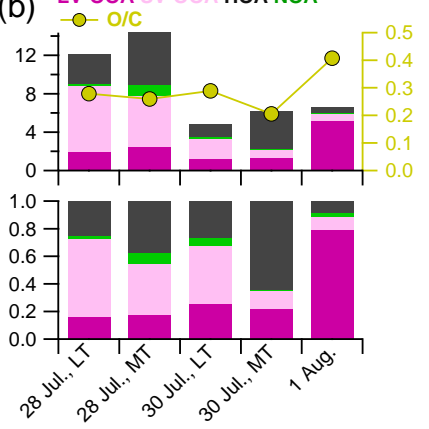

Fig. 3. Average composition of (a) NR-PM 1 and (b) OA for each roadside measurement. Each morning measurement was further classified into two events with less traffic (LT) and more traffic (MT) influences, respectively. Details are described in the text. In addition, the $\mathrm{O} / \mathrm{C}$ ratio for each event is also shown in (b).

on 27 July are found to have a large interference from the ASRC-ML generator exhaust with silicone contamination (see supplementary information for details), thus our discussions focus on the other three observations. The inorganic species (sulfate, nitrate, and ammonium) vary smoothly throughout the two mornings of 28 and 30 July. This is not surprising because vehicles are not direct emitters of nitrate aerosols (Gillies et al., 2001), and the introduction of ultra-low sulfur fuel ( $<15 \mathrm{ppm} \mathrm{S}$ by weight) leads to very low emissions of sulfur in New York. Their variations are thus mainly controlled by meteorological variables, boundary layer height, and also likely photochemical reactions. Organic aerosols, however, show different behaviors between the early and late mornings. Organics show smooth varia-

tions in early mornings, e.g. before 05:30 a.m. on 28 July and 07:30 a.m. on 30 July, while vary dramatically with frequent spikes during late morning periods due to the penetration of roadway plumes. A further analysis of the variations of OA components (Fig. 2) indicates that the organic spikes are primarily caused by the HOA, a surrogate of primary emissions from vehicles. Note that the intensities of the spikes fluctuate on time scale of a minute, which reflect the rapid temporal changes in traffic flow, traffic type, and meteorology. The variation of LV-OOA is small throughout the morning, which can be explained by its regional characteristics since photochemical production of secondary OA (SOA) would not play significant roles in the mornings. We also observed a decrease of SV-OOA after sunrise for the two morning experiments (e.g. from 2.0 to $0.8 \mu \mathrm{g} \mathrm{m}^{-3}$ after 07:30 a.m. on 30 July), likely due to the dilution from HOA-dominated traffic plumes near highway. Note that the SV-OOA shows an increase from $\sim 6$ to $\sim 9 \mu \mathrm{g} \mathrm{m}^{-3}$ at around 05:30 a.m. on 28 July. Such increase co-varies with those of inorganic species (sulfate, nitrate, and ammonium), which is likely due to a small change of air mass. Compared to the two morning measurements, all aerosol species co-vary in the evening on 30 July (e.g. $r^{2}=0.49-0.57$ between organics and inorganic species), consistent with the internally mixed characteristics of aerosol particles (see Sect. 3.2). Note that the average mass concentration of NR-PM 1 is $20.7 \mu \mathrm{g} \mathrm{m}^{-3}$ on 28 July, about twice as high as the 8.5 and $11.9 \mu \mathrm{g} \mathrm{m}^{-3}$ measured on 30 July and 1 August, respectively, mainly due to the stagnant conditions associated with low wind speed $\left(<2 \mathrm{~m} \mathrm{~s}^{-1}\right)$. This is consistent with the observation of high aerosol optical depth (AOD) values across the whole northeast US on 28 July, while relatively low AOD on the other 
(a) 28 July

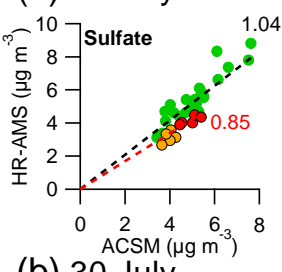

(b) 30 July

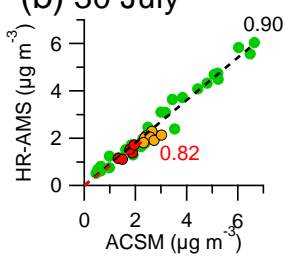

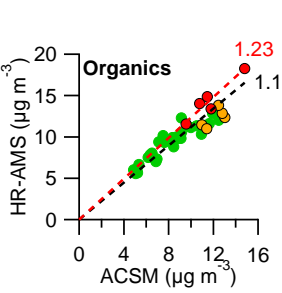

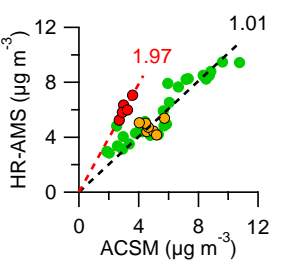

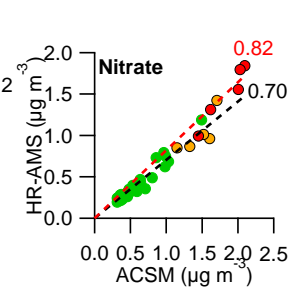

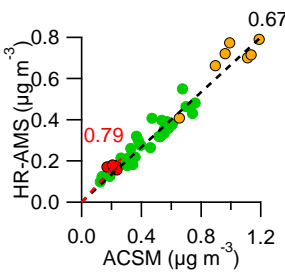

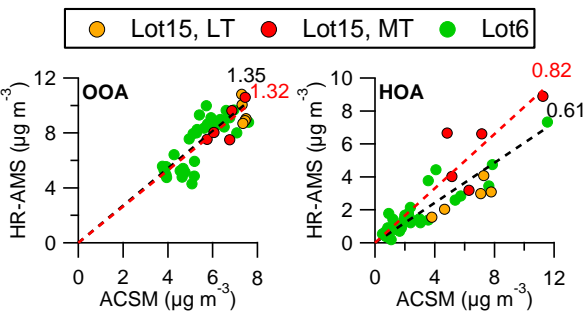
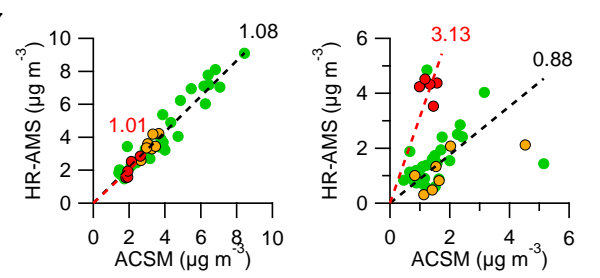

Fig. 4. Comparisons of mass concentrations of sulfate, organics, nitrate, OOA and HOA measured at Lot 15 by HR-AMS and DEC monitoring station by ACSM on (a) 28 July and (b) 30 July. The green solid circles show the comparisons of synchronous measurements at Lot 6 and DEC monitoring station in the same day. The orange and red solid circles refer to the data points during LT and MT, respectively. The numbers shown on the plots are linear regression slope with intercept forcing to zero.

two days (Fig. S1). The aerosol composition shows differences between mornings and evenings, but overall, organics is the major component, accounting for more than half of total NR-PM 1 mass (range: 55-74\%), with sulfate being the second most abundant species.

To better characterize the impact of traffic plumes on aerosol composition, each morning measurement was further classified into two events, i.e. less traffic (LT) and more traffic (MT) that were separated at 05:30 a.m. and 07:30 a.m. on 28 and 30 July, respectively. The separation of LT and MT is mainly based on the variations of primary $\mathrm{HOA}, \mathrm{BC}$, and $\mathrm{NO}_{\mathrm{x}}$. The NR-PM 1 shows very similar average bulk composition before and after 05:30 a.m. on 28 July regardless of the traffic influences, due to the persistent wind from the direction of the campus of QC rather than from the LIE highway throughout the morning. However, the OA composition shows differences with $\sim 12 \%$ enhancement of HOA contribution to OA during the MT event. This is consistent with a synchronous elevation of ultrafine mode organics (Sect. 3.2) while the accumulation mode remains unchanged. Since the wind direction was from the south, the enhancements of HOA and ultrafine mode organics are likely due to the MTA bus emissions at the bus stop rather than from the LIE. Note that since the wind data shown in Fig. 2 were acquired from the DEC building on campus, where the local wind pattern might be different than that at the roadside site. Comparatively, 30 July shows significant differences in aerosol composition between the LT and MT events associated with a change in wind direction from the QC campus to the LIE. The contribution of organics is therefore elevated by $18 \%$, accounting for $74 \%$ of total NR-PM 1 mass during the MT event. The HOA contribution jumps from $27 \%$ to $62 \%$, associated with a decrease of SV-OOA from $42 \%$ to $13 \%$ of OA. We didn't observe clear traffic influences on
1 August, consistent with the OA composition being dominated by LV-OOA (79\%) with a minor contribution of HOA ( $\sim 9 \%)$. The significantly different composition might be related to the low traffic flow with less diesel trucks $(\sim 1.2 \%$ of total vehicles) on Saturday.

We further compared the aerosol measurements near highway by the HR-AMS and at the campus site by the ACSM. The synchronous measurements in the same day at Lot 6 by the HR-AMS and at the DEC building by the ACSM are plotted as a comparison (Fig. 4 and Fig. S2). As shown in Fig. 4, sulfate near the roadway appears to be $\sim 10-15 \%$ lower than at the campus site on both 28 and 30 July. Nitrate does not show significant differences between the two sites in both two mornings. Organics show slightly higher concentration after 05:30 a.m. on 28 July due to traffic influences. Figure $4 \mathrm{~b}$ further demonstrates that the slightly higher OA during MT is mainly caused by HOA rather than OOA. Given that the roadside and campus sites are both located upwind of the LIE on 28 July (wind direction from $S$ and SW), the sporadic traffic spikes observed might be mainly due to the influences of MTA bus emissions rather than the LIE traffic emissions. Comparatively, while the organic concentrations at the roadside before 07:30 a.m. on 30 July are very close to those observed at the campus site, it was almost twice elevated after 07:30 a.m. due to the influences of traffic plumes from the LIE. The HOA concentration near roadway is more than 3 times elevated in comparison to the campus site while OOA concentration is similar between these two sites. These results overall suggest that traffic plumes show the biggest impact on HOA, but minor effects on inorganic species and OOA. 
Table 1. Mass concentrations $\left(C_{i}\right)$ and median diameters $\left(D_{\mathrm{va}, i}\right)$ of the modes calculated from lognormal fitting of average size distributions of organics during less traffic (LT) and more traffic (MT) periods on 28 July and 30 July, respectively.

\begin{tabular}{lrrrrrrr}
\hline & & $\begin{array}{r}D_{\mathrm{va}, 1} \\
\mathrm{~nm}\end{array}$ & $\begin{array}{r}C_{1} \\
\mu \mathrm{g} \mathrm{m}^{-3}\end{array}$ & $\begin{array}{r}D_{\mathrm{va}, 2} \\
\mathrm{~nm}\end{array}$ & $\begin{array}{r}C_{2} \\
\mu \mathrm{g} \mathrm{m}^{-3}\end{array}$ & $\begin{array}{r}D_{\mathrm{va}, 3} \\
\mathrm{~nm}\end{array}$ & $\begin{array}{r}C_{3} \\
\mu \mathrm{g} \mathrm{m}^{-3}\end{array}$ \\
\hline \multirow{2}{*}{ 28-July } & LT & 127 & 4.5 & 548 & 6.5 & 655 & 1.3 \\
& MT & 120 & 6.6 & 567 & 7.7 & & \\
\hline \multirow{2}{*}{$30-$ July } & LT & 119 & 1.0 & 386 & 2.2 & 622 & 1.5 \\
& MT & 129 & 2.6 & & & 539 & 3.3 \\
\hline
\end{tabular}
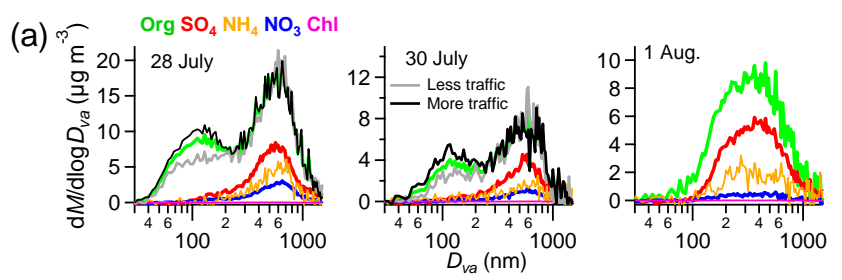

(b)

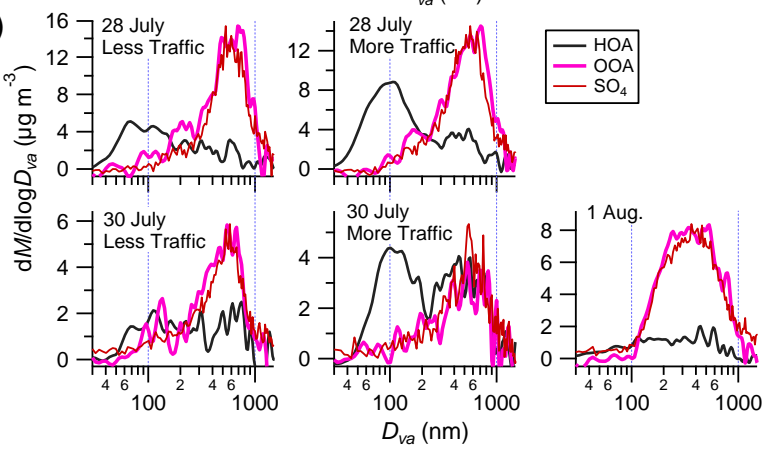

Fig. 5. Average size distributions of (a) $\mathrm{NR}-\mathrm{PM}_{1}$ species and (b) HOA and OOA. The size distributions of organics with less and more traffic influences in two mornings are also shown in (a). The size distributions of sulfate that were scaled to the peak values are shown in (b) for a reference. Note that the size distributions of HOA and OOA were smoothed by 3 points using binominal algorithm.

\subsection{Size distributions}

Figure 5 shows the average size distributions of NR-PM species and OA components for the three experiments. Organics present distinct bimodal mass-weighted distributions during the two morning events which are characterized by an ultrafine mode peaking at $\sim 120 \mathrm{~nm}$, and a large accumulation mode peaking at $\sim 500-600 \mathrm{~nm}$. The inorganic species, however, show a single accumulation mode overlapping with that of organics. The ultrafine mode, also known as the "traffic" mode, with dominant contribution by organics has been observed previously at the same site (Drewnick et al., 2004) and other urban sites (Allan et al., 2003; Alfarra et al., 2004; Zhang et al., 2005b), and also in vehicle exhausts from chase studies (Canagaratna et al., 2004, 2010). The ultrafine mode organics show good correlations with HOA (e.g. $r^{2}=0.69$ and 0.59 , respectively, on 28 July and 30 July for the correlations between organics in the size range of $30-200 \mathrm{~nm}$ and HOA), demonstrating the dominant contribution of traffic emissions to this mode. The size distributions of OA components further confirm that the "traffic" mode is primarily contributed by HOA with only a minor contribution from OOA (Fig. 5b). A comparison of the size distributions of organics between LT and MT (Fig. 5a) shows a significant enhancement of the ultrafine mode organics while the accumulation mode shows little change. In order to determine the enhancement, a log-normal fitting (Seinfeld and Pandis, 2006) was performed to the size distributions of organics on 28 and 30 July. Generally, 2 modes and sometimes 3 modes are needed to obtain the best log-normal fit. The fitting results including the mass concentration and mean diameter for each mode are shown in Table 1 and Fig. S3. The results show that the "traffic" mode during the period with more traffic influences is elevated by $\sim 50 \%$ from 4.5 to $6.6 \mu \mathrm{g} \mathrm{m}^{-3}$ on $28 \mathrm{July}$, and 2.6 times from 1.0 to $2.6 \mu \mathrm{g} \mathrm{m}^{-3}$ on 30 July. The accumulation modes, on the other hand, show little variations. The same comparisons applied to OA components suggest that the enhancement of "traffic" mode organics is primarily due to HOA. In fact, HOA during MT on 28 July shows a small particle mode similar to the BC measured along the LIE by a Soot-Particle AMS (SP-AMS) (Massoli et al., 2012). This further demonstrates the primary characteristics of "traffic" mode organics. The simultaneous measurements carried out at Lot 6 also presented similar bimodal distributions for the HOA tracer $-\mathrm{C}_{4} \mathrm{H}_{9}^{+}(m / z 57)$ in the morning (Sun et al., 2011b). All these results suggest that the "traffic" mode organics are externally mixed with secondary inorganic species. OOA, however, shows very similar size distributions to sulfate for all events despite the traffic influences, implying that these two species are secondary in nature and likely internally mixed. The aerosol species and OA components in the evening of 1 Aug. also present a very similar and single large accumulation mode, indicating that they are internally mixed, consistent with the tight correlations between organics and sulfate $\left(r^{2}=0.53\right)$ and the overall aged $\mathrm{OA}(\mathrm{O} / \mathrm{C}=0.41)$. 

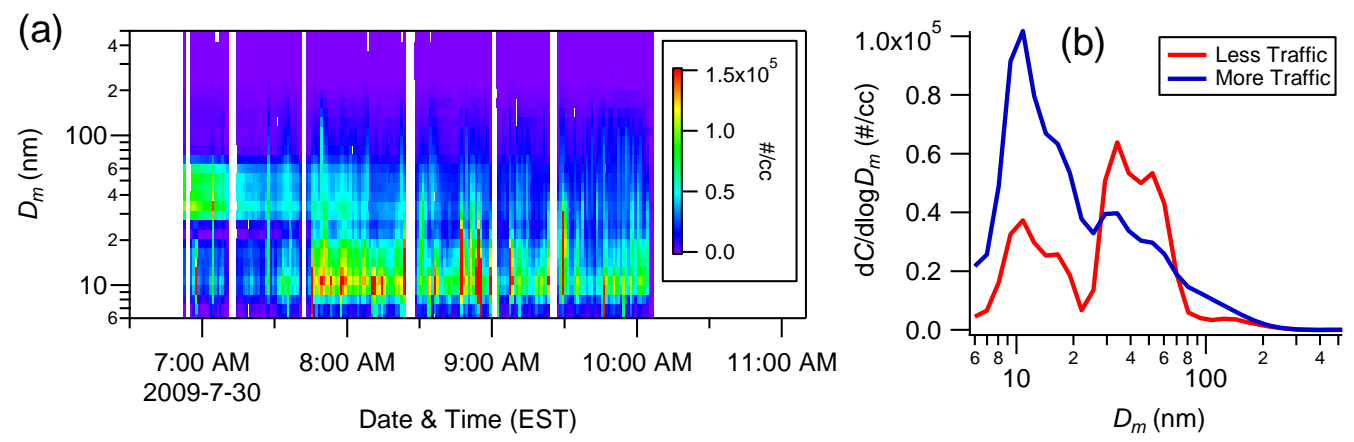

Fig. 6. (a) size-resolved number concentrations measured by the FMPS on 30 July. (b) shows the average size distributions of number concentrations before 07:30 a.m. (less traffic) and after 07:30 a.m. (more traffic), respectively.

Figure 6 shows the evolution of the number distributions on 30 July measured by the FMPS. Due to the influences of traffic emissions, the number distributions show a dramatic change at 07:30 a.m. Before 07:30 a.m., the numberweighted concentrations show a trimodal structure, peaking at $\sim 11 \mathrm{~nm}, \sim 40 \mathrm{~nm}$, and $140 \mathrm{~nm}$ (mobility diameter, $D_{\mathrm{m}}$ ), respectively. In addition, the second mode is more significant than the first mode. After 07:30 a.m., the number concentrations are characterized by a burst of particles at $D_{\mathrm{m}}=\sim 10 \mathrm{~nm}$ associated with a decrease of large particles due to the traffic influences from the LIE. The distributions show multiple modes, similar to those observed at $\sim 30 \mathrm{~m}$ downwind of a highway in Los Angeles (Zhu et al., 2002b). The significant enhancement of the number concentration of ultrafine particles near highway in comparison to hundreds of meters downwind has been observed widely (Kirchstetter et al., 1999; Zhu et al., 2002a; Zavala et al., 2009). The comparison of the volume-weighted size distribution from the FMPS measurement with the mass-weighted size distribution from the HR-AMS measurement on 30 July is shown in Fig. S9. The relationship of $D_{\mathrm{va}}$ and $D_{\mathrm{m}}$ is given in Eq. (1) assuming the particles are spherical (DeCarlo et al., 2004).

$D_{\mathrm{va}}=D_{\mathrm{m}} \times \frac{\rho_{\mathrm{eff}}}{\rho_{0}}$

Where $\rho_{\text {eff }}$ is particle "effective" densities which can be estimated from the particle composition, $\rho_{0}$ is the standard density $1 \mathrm{~g} \mathrm{~cm}^{-3}$. Assuming an average density of $1.75 \mathrm{~g} \mathrm{~cm}^{-3}$ for inorganic species $\left(\mathrm{NH}_{4}^{+}+\mathrm{NO}_{3}^{-}+\mathrm{SO}_{4}^{2-}\right)$ (Lide, 1992), $1.2 \mathrm{~g} \mathrm{~cm}^{-3}$ for organics (Turpin and Lim, 2001), and $1.77 \mathrm{~g} \mathrm{~cm}^{-3}$ for black carbon (Park et al., 2004; Bond and Bergstrom, 2006), we estimate that the average densities of aerosol particles are $1.42 \mathrm{~g} \mathrm{~cm}^{-3}$ and $1.43 \mathrm{~g}$ $\mathrm{cm}^{-3}$, respectively, during LT and MT on 30 July. Note that the size distributions from FMPS and HR-AMS measurements are quite different because they measure different diameters which are affected significantly by particle shape (DeCarlo et al., 2004). A previous study at Pittsburgh also observed significantly different size distributions between

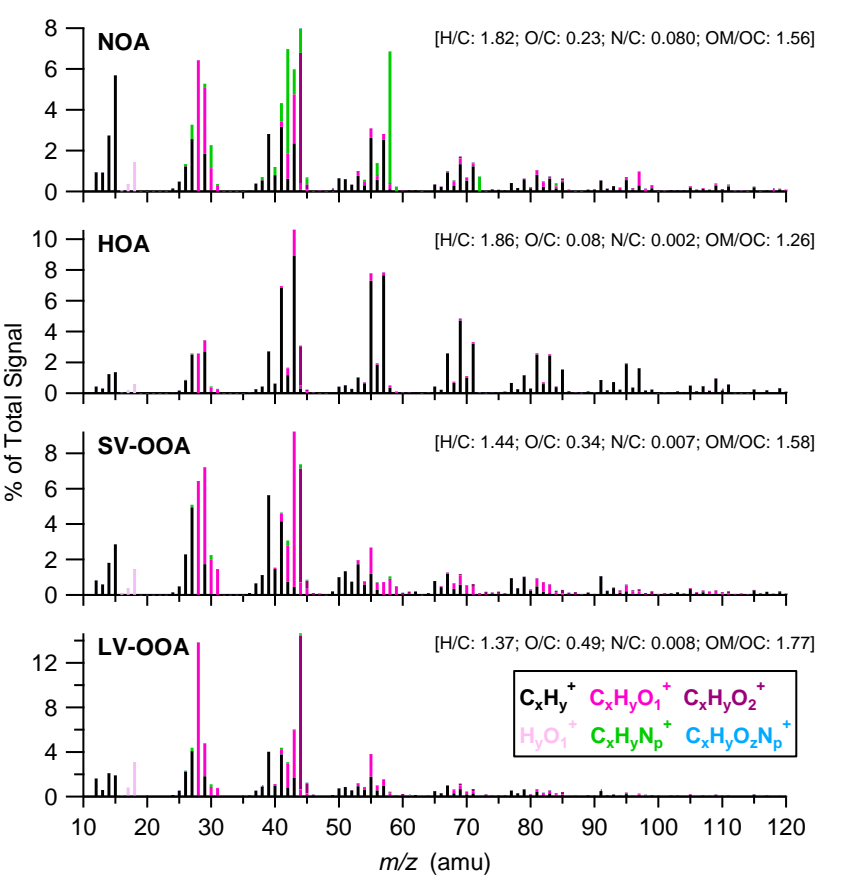

Fig. 7. High resolution mass spectra of OA components. The elemental ratios and $\mathrm{OM} / \mathrm{OC}$ ratio of each component are also shown in the legends.

scanning mobility particle sizer (SMPS) and QuadrupoleAMS, especially when BC plays an important role in particle composition (Zhang et al., 2005b).

\subsection{Investigation of $\mathrm{OA}$ near roadway}

The mass spectra and time series of the four OA components identified near roadway are shown in Figs. 7 and 2, respectively. The mass spectra of OA components show very similar spectral patterns to those identified at Lot 6 (Fig. S4). Briefly, LV-OOA is characterized by the high $\mathrm{m} / \mathrm{z} 44$ (mainly $\mathrm{CO}_{2}^{+}$) and $\mathrm{O} / \mathrm{C}$ ratio (0.49), showing overall resemblance to those observed at other sites (e.g. Aiken et al., 


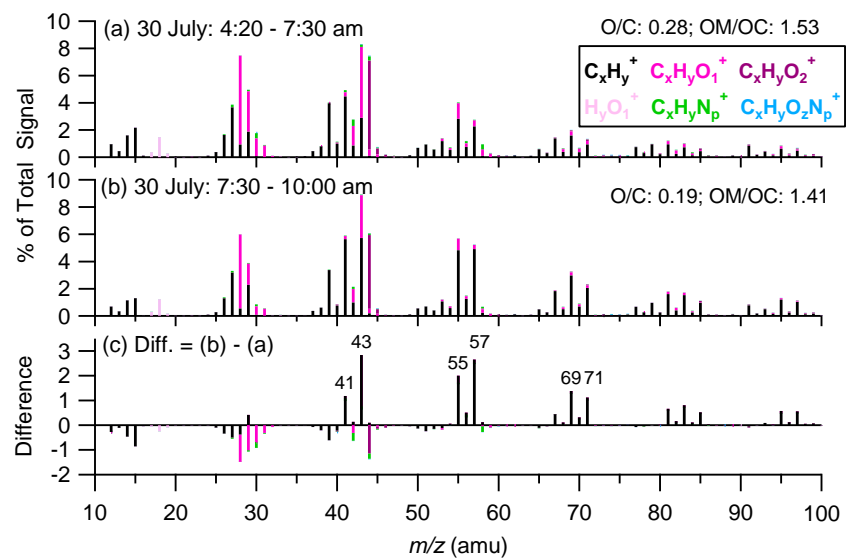

Fig. 8. Average high resolution mass spectra of OA (a) before and (b) after 07:30 a.m. on 30 July. (c) shows the difference spectra between (b) and (a).

2010; Allan et al., 2010; DeCarlo et al., 2010; Hildebrandt et al., 2010). SV-OOA $(\mathrm{O} / \mathrm{C}=0.34)$ represents a less oxidized component characterized by a higher ratio of $\mathrm{m} / \mathrm{z} 43$ to 44. HOA, on the other hand, shows the typical hydrocarbon ion series $\left(\mathrm{C}_{n} \mathrm{H}_{2 n-1}^{+}\right.$and $\left.\mathrm{C}_{n} \mathrm{H}_{2 n+1}^{+}\right)$as previously reported (e.g. Zhang et al., 2005a). Similar to the NOA observed at Lot 6 (Sun et al., 2011b) the NOA near roadway is also characterized by amine-type of ions, e.g. $\mathrm{C}_{2} \mathrm{H}_{6} \mathrm{~N}^{+}, \mathrm{C}_{3} \mathrm{H}_{8} \mathrm{~N}^{+}$, and $\mathrm{C}_{4} \mathrm{H}_{10} \mathrm{~N}^{+}$etc. But overall NOA is only a minor fraction of total OA $(<8 \%)$ at both roadside and Lot 6 . Note that LV-OOA and SV-OOA observed near roadway appear to be slightly less oxidized in comparison to those observed at Lot $6(\mathrm{O} / \mathrm{C}: 0.49$ vs. 0.63 for $\mathrm{LV}-\mathrm{OOA}$, and 0.34 vs. 0.38 for SV-OOA). Figure 8 shows a comparison of the HRMS before and after 07:30 a.m. on 30 July. The difference spectrum (Fig. 8c) is characterized by prominent peaks at $\mathrm{m} / \mathrm{z} 41$ $\left(\mathrm{C}_{3} \mathrm{H}_{5}^{+}\right), 43\left(\mathrm{C}_{3} \mathrm{H}_{7}^{+}\right), 55\left(\mathrm{C}_{4} \mathrm{H}_{7}^{+}\right), 57\left(\mathrm{C}_{4} \mathrm{H}_{9}^{+}\right), 69\left(\mathrm{C}_{5} \mathrm{H}_{9}^{+}\right)$, and $71\left(\mathrm{C}_{5} \mathrm{H}_{11}^{+}\right)$which are the typical $\mathrm{m} / z$ 's of particles from vehicle exhaust (Canagaratna et al., 2004), confirming the significant traffic influences after 07:30 a.m.

HOA correlates well with $\mathrm{BC}\left(r^{2}=0.52\right)$ and $\mathrm{NO}_{\mathrm{x}}$ $\left(r^{2}=0.56\right)$ on 30 July (Fig. 9). This is consistent with the conclusion from a number of studies that HOA is likely a surrogate for combustion POA associated with traffic emissions (Zhang et al., 2005c, 2007; Aiken et al., 2009; Ulbrich et al., 2009). The linear regression slope of $\mathrm{HOA} / \mathrm{NO}_{\mathrm{x}}$ $\left(=0.044 \mu \mathrm{g} \mathrm{m}^{-3} \mathrm{ppbv}^{-1}\right)$ is close to the value observed at Lot $6(0.045)$, while that of HOA/BC is slightly lower (1.02 vs. 1.29 at Lot 6$)$. It's interesting to note that HOA does not correlate with BC on 28 July $\left(r^{2}=0.03\right)$, suggesting different impacts from traffic emissions on $\mathrm{HOA}$ and $\mathrm{BC}$ on 28 July. Indeed, the vehicle chase study conducted on the same day shows that the emissions of organics, $\mathrm{BC}, \mathrm{CO}_{2}$, and $\mathrm{NO}_{\mathrm{x}}$ strongly depend on the types of vehicles (Massoli et al., 2012). Heavy and medium duty trucks and the NYC
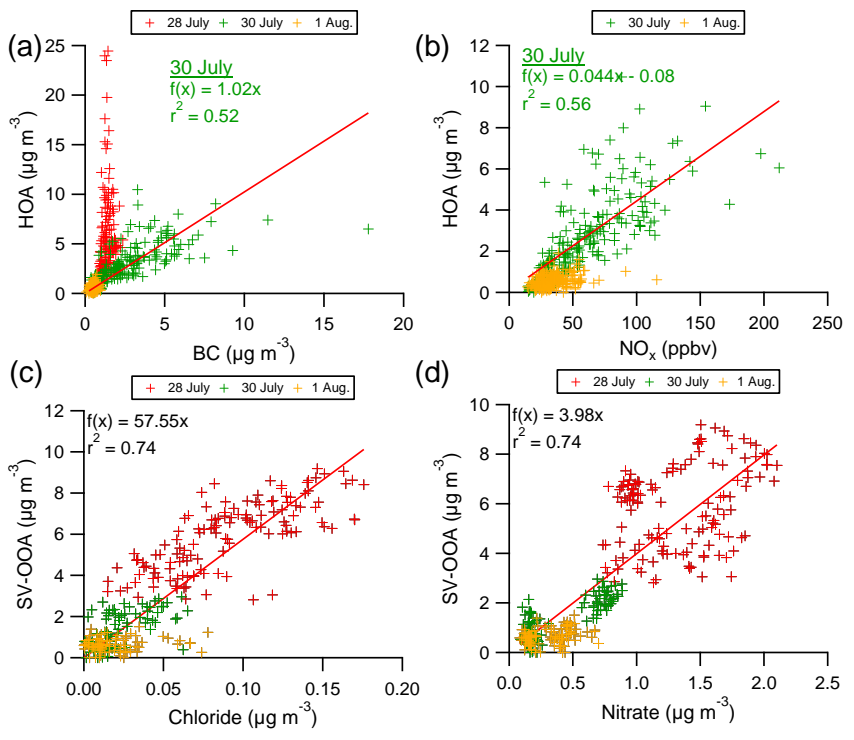

Fig. 9. Correlation plots of (a) $\mathrm{HOA}$ vs. $\mathrm{BC}$, (b) $\mathrm{HOA}$ vs. $\mathrm{NO}_{\mathrm{x}}$ $\left(\mathrm{NO}+\mathrm{NO}_{2}\right)$, (c) SV-OOA vs. Chloride, (d) SV-OOA vs. nitrate. Missed $\mathrm{BC}$ and $\mathrm{NO}_{\mathrm{x}}$ data are due to either the malfunction of instruments or non-operating because of limited power supply.

Metropolitan Transit Authority (MTA) standard buses emit large quantities of both $\mathrm{OA}$ and $\mathrm{BC}$, while MTA buses using clean technology such as compressed natural gas $(\mathrm{CNG})$ and hybrid buses emit less OA and almost no BC (Massoli et al., 2012). A chase study conducted in 2000 during the $\mathrm{PM}_{2.5}$ Technology Assessment and Characterization Study in NYC (PMTACS-NY) investigated particulate emissions from inuse NYC vehicles and showed that diesel buses have much larger emission ratios $\left(0.10-0.23 \mathrm{~g}\right.$ NR-PM $\mathrm{kg}^{-1}$ Fuel) than those fueled by CNG $\left(0.034 \mathrm{~g} \mathrm{NR}-\mathrm{PM}_{1} \mathrm{~kg}^{-1}\right.$ Fuel) (Canagaratna et al., 2004). These results might explain our observations of primary OA plumes with no simultaneous increase of $\mathrm{BC}$ concentration, i.e. NR-PM $\mathrm{P}_{1}$ in the morning of 28 July were mainly influenced by the emissions from the nearby MTA bus stop, where CNG buses emit a large fraction of OA and minor amounts of BC. This also suggests that our sampling site is less affected by the high traffic flow ( $\sim 10000$ vehicles per hour, of which $\sim 12 \%$ is diesel trucks based on our manual counting) on 28 July.

We further calculated the emission ratios (ER) of HOA and $\mathrm{BC}$ from the LIE during the MT period on 30 July. The ER on 28 July was not calculated since the ASRC-ML is located upwind of the LIE and did not capture the direct vehicle emissions from the highway. It should be noted that the ER calculated in this study is more representative of the average mixed emissions from all types of vehicles on the LIE, which is different from those of individual vehicles from chase studies. The ER can be calculated as (1) $\mathrm{ER}=\Delta$ Signal $/ \Delta \mathrm{CO}_{2}$, where $\Delta \mathrm{CO}_{2}$ is the difference of $\mathrm{CO}_{2}$ and background $\mathrm{CO}_{2}$ or (2) by performing a linear fit to 
$\mathrm{HOA}$ or $\mathrm{BC}$ versus $\Delta \mathrm{CO}_{2}$ (Fig. 10). The background $\mathrm{CO}_{2}$ ( $\sim 410 \mathrm{ppm}$ on 30 July) was calculated as the average of the lowest $5 \%$ of data during the sampling period. The ER calculated from the two methods above are consistent, e.g. 0.20 vs. $0.18 \mu \mathrm{g} \mathrm{m}^{-3}$ of HOA per ppm of $\mathrm{CO}_{2}$. Given that the variations of NR-PM 1 after 07:30 a.m. on 30 July are overwhelmingly controlled by HOA, the ER of HOA would be

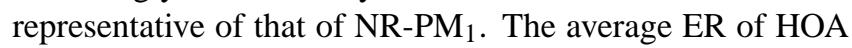
agrees within the range of ERs obtained by chasing different types of vehicles in NYC in $2000\left(\sim 0.02-0.32 \mu \mathrm{g} \mathrm{m}^{-3}\right.$ NR-PM $\mathrm{ppm}^{-1} \mathrm{CO}_{2}$ ) (Canagaratna et al., 2004). This implies that the vehicle emissions of organics in relative to $\mathrm{CO}_{2}$ did not likely reduce, at least not significantly, during the period of 2000-2009. This conclusion is also supported by the observation that the mass concentrations of OA in 2009 (Sun et al., 2011b) show a slight increase in comparison to those observed in the same month in 2001 (Weimer et al., 2006), though sulfate has been considerably reduced, likely due to the introduction of ultra-low sulfur fuel. BC shows comparable ER $\left(0.19 \mu \mathrm{g} \mathrm{m}^{-3} \mathrm{ppm}^{-1} \mathrm{CO}_{2}\right)$ as that of HOA (Fig. 9a). HOA and BC together contribute an average emission of $\sim 0.4 \mu \mathrm{g} \mathrm{m}^{-3} \mathrm{PM}_{1} / \mathrm{ppm} \mathrm{CO} \mathrm{CO}_{2}$, corresponding to an emission index (EI) of $\sim 0.71 \mathrm{~g} \mathrm{PM}_{1} \mathrm{~kg}^{-1}$ fuel assuming that the weight fraction of carbon in diesel fuel $\left(W_{\mathrm{c}}\right)$ is 0.87 (Kirchstetter et al., 1999; Canagaratna et al., 2004).

$\mathrm{EI}=(\mathrm{ER} \times 490.8) \times 10^{3} \times W_{\mathrm{c}}$

Where 490.8 is the constant used to convert $\mathrm{CO}_{2}$ concentration from ppm to $\mu \mathrm{gC} \mathrm{m}^{-3}$ for ambient temperature $(290 \mathrm{~K})$ and pressure $(101.3 \mathrm{kPa})$. The average $\mathrm{EI}$ of $\mathrm{BC}$ is estimated at $0.34 \mathrm{~g} \mathrm{~kg}^{-1}$, which is overall consistent with the results from the "chase" study on 28 July 2009 by the AerodyneML in the same campaign that the EI of BC under the traffic conditions being dominated by the light-duty vehicles and heavy-duty vehicles is 0.04 and $0.46 \mathrm{~g} \mathrm{~kg}^{-1}$, respectively (Massoli et al., 2012). Note that the emission ratio calculated here represents an average value under mixed-traffic conditions (i.e. gasoline and diesel vehicles) downwind of the LIE on one day. It might vary significantly depending on traffic types and driving conditions on different days.

\section{Conclusions and implications}

We have characterized the mass concentrations, chemical composition and size distributions of submicron aerosol species in the vicinity of a major highway in NYC with an Aerodyne HR-AMS deployed inside the ASRC-ML. Four experiments were conducted on different days with two in the morning and two in the evening. Our results show that the organic aerosols vary dramatically due to influences from vehicle emissions near roadway, while inorganic species including sulfate and nitrate show relatively smooth variations. The enhancements of aerosol particle mass observed during traffic-influenced periods are therefore mainly attributed to
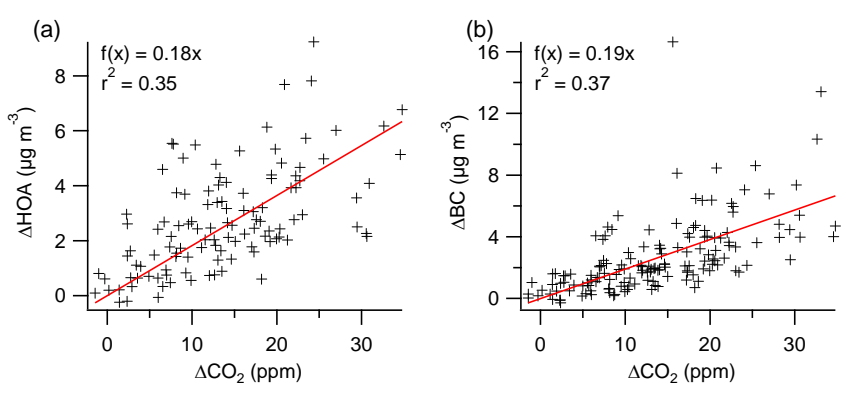

Fig. 10. Correlation plots of (a) $\triangle \mathrm{HOA}$ vs. $\Delta \mathrm{CO}_{2}$, (b) $\Delta \mathrm{BC}$ vs. $\Delta \mathrm{CO}_{2}$ during the period with more traffic influences, i.e. after 07:30 a.m. on 30 July.

organics. Also, the mass concentration and chemical composition of submicron particles vary significantly from day to day, but overall organics compose a major fraction (55$74 \%$ ) of the total $\mathrm{PM}_{1}$ mass. Distinct mass-weighted bimodal distributions, peaking at $\sim 120 \mathrm{~nm}$ and $550 \mathrm{~nm}\left(D_{\text {va }}\right)$, respectively, are observed for organics in the two morning measurements. Inorganic species (sulfate, ammonium, and nitrate) present a single large accumulation mode, peaking at $\sim 550 \mathrm{~nm}$. The different size distributions between organic and inorganic species suggest that fresh traffic-emitted particles are externally mixed with more aged, secondary particles. Significant enhancements in ultrafine organic aerosol mass concentrations and particle number concentrations at $\sim 10 \mathrm{~nm}\left(D_{\mathrm{m}}\right)$ are frequently observed in traffic plumes. A further analysis of OA composition and size distributions suggests that the ultrafine mode organics are dominated by HOA from vehicle emissions near highway. OOA in the large accumulation mode, however, shows minor influences from traffic emissions. In comparison to the morning experiments, all NR-PM 1 species appear to be internally mixed in a broader accumulation mode with OA composition being dominated by OOA in an evening on Saturday, likely due to relatively low traffic flow and consistent northwesterly wind that blew the highway traffic plumes away from our sampling site.

While this study does not provide direct information on particle toxicity and health impacts, our results might nevertheless have significant implications for near-highway air pollution characterization and exposure assessments. For example, the fact that the mass concentrations, chemical composition and size distributions of submicron particles change rapidly over short distances near highways suggests that people living in close proximity to the highways are regularly exposed to higher level of particle pollution than people living far away and that PM exposure assessments should take into account of the temporal and spatial variations in aerosol loading and properties near roadways. Since aerosol changes are found strongly dependent on wind direction and speed, mixed layer height, vehicle types, and traffic flow, 
additional studies are needed to thoroughly assess their impacts on near roadway air quality. In addition, long-term, continuous measurements of air pollutants near highways are necessary to characterize their diurnal, weekly, and seasonal variation profiles, all of which are important for interpreting epidemiological studies of ambient air pollution.

\section{Supplementary material related to this article is available online at: http://www.atmos-chem-phys.net/12/2215/2012/ acp-12-2215-2012-supplement.pdf.}

Acknowledgements. This study was supported by the Office of Science (BER), US Department of Energy, Atmospheric Systems Research (ASR) Program (Grants No. DE-FG02-08ER64627, DE-SC0002191), the One Hundred Person Project of the Chinese Academy of Sciences, New York State Energy Research and Development Authority, New York State Department of Environmental Conservation, and New York State Office of Science, Technology and Academic Research. We thank the New York State Department of Environmental Conservation for use of their facility, and particularly Mike Christopherson, Ed Marion, and Dirk Felton. We thank the Queens College administration and staff, especially Wing Chan, for hosting this study.

Edited by: F. Yu

\section{References}

Aiken, A. C., DeCarlo, P. F., Kroll, J. H., Worsnop, D. R., Huffman, J. A., Docherty, K. S., Ulbrich, I. M., Mohr, C., Kimmel, J. R., Sueper, D., Sun, Y., Zhang, Q., Trimborn, A., Northway, M., Ziemann, P. J., Canagaratna, M. R., Onasch, T. B., Alfarra, M. R., Prevot, A. S. H., Dommen, J., Duplissy, J., Metzger, A., Baltensperger, U., and Jimenez, J. L.: O/C and OM/OC ratios of primary, secondary, and ambient organic aerosols with HighResolution Time-of-Flight Aerosol Mass Spectrometry, Environ. Sci. Technol., 42, 4478-4485, 2008

Aiken, A. C., Salcedo, D., Cubison, M. J., Huffman, J. A., DeCarlo, P. F., Ulbrich, I. M., Docherty, K. S., Sueper, D., Kimmel, J. R., Worsnop, D. R., Trimborn, A., Northway, M., Stone, E. A., Schauer, J. J., Volkamer, R. M., Fortner, E., de Foy, B., Wang, J., Laskin, A., Shutthanandan, V., Zheng, J., Zhang, R., Gaffney, J., Marley, N. A., Paredes-Miranda, G., Arnott, W. P., Molina, L. T., Sosa, G., and Jimenez, J. L.: Mexico City aerosol analysis during MILAGRO using high resolution aerosol mass spectrometry at the urban supersite (T0) - Part 1: Fine particle composition and organic source apportionment, Atmos. Chem. Phys., 9, 66336653, doi:10.5194/acp-9-6633-2009, 2009.

Aiken, A. C., de Foy, B., Wiedinmyer, C., DeCarlo, P. F., Ulbrich, I. M., Wehrli, M. N., Szidat, S., Prevot, A. S. H., Noda, J., Wacker, L., Volkamer, R., Fortner, E., Wang, J., Laskin, A., Shutthanandan, V., Zheng, J., Zhang, R., Paredes-Miranda, G., Arnott, W. P., Molina, L. T., Sosa, G., Querol, X., and Jimenez, J. L.: Mexico city aerosol analysis during MILAGRO using high resolution aerosol mass spectrometry at the urban supersite (T0) - Part 2: Analysis of the biomass burning contribution and the non-fossil carbon fraction, Atmos. Chem. Phys., 10, 5315-5341, doi:10.5194/acp-10-5315-2010, 2010.

Alfarra, M. R., Coe, H., Allan, J. D., Bower, K. N., Boudries, H., Canagaratna, M. R., Jimenez, J. L., Jayne, J. T., Garforth, A., Li, S.-M., and Worsnop, D. R.: Characterization of urban and regional organic aerosols in the Lower Fraser Valley using two Aerodyne Aerosol Mass Spectrometers, Atmos. Environ., 38, 5745-5758, 2004.

Allan, J. D., Alfarra, M. R., Bower, K. N., Williams, P. I., Gallagher, M. W., Jimenez, J. L., McDonald, A. G., Nemitz, E., Canagaratna, M. R., Jayne, J. T., Coe, H., and Worsnop, D. R.: Quantitative sampling using an Aerodyne Aerosol Mass Spectrometer. Part 2: Measurements of fine particulate chemical composition in two UK Cities, J. Geophys. Res.-Atmos., 108, 4091, doi:4010.1029/2002JD002359, 2003.

Allan, J. D., Williams, P. I., Morgan, W. T., Martin, C. L., Flynn, M. J., Lee, J., Nemitz, E., Phillips, G. J., Gallagher, M. W., and Coe, H.: Contributions from transport, solid fuel burning and cooking to primary organic aerosols in two UK cities, Atmos. Chem. Phys., 10, 647-668, doi:10.5194/acp-10-647-2010, 2010.

Amato, F., Viana, M., Richard, A., Furger, M., Prévôt, A. S. H., Nava, S., Lucarelli, F., Bukowiecki, N., Alastuey, A., Reche, C., Moreno, T., Pandolfi, M., Pey, J., and Querol, X.: Size and timeresolved roadside enrichment of atmospheric particulate pollutants, Atmos. Chem. Phys., 11, 2917-2931, doi:10.5194/acp-112917-2011, 2011.

Ban-Weiss, G. A., Lunden, M. M., Kirchstetter, T. W., and Harley, R. A.: Size-resolved particle number and volume emission factors for on-road gasoline and diesel motor vehicles, J. Aerosol Sci., 41, 5-12, 10.1016/j.jaerosci.2009.08.001, 2010.

Bond, T. C. and Bergstrom, R. W.: Light Absorption by Carbonaceous Particles: An Investigative Review, Aerosol Sci. Tech., 40, 27-67, 2006.

Brugge, D., Durant, J., and Rioux, C.: Near-highway pollutants in motor vehicle exhaust: A review of epidemiologic evidence of cardiac and pulmonary health risks, Environmental Health, 6, 23, doi:10.1186/1476-069X-6-23, 2007.

Brunekreef, B., Janssen, N. A. H., de Hartog, J., Harssema, H., Knape, M., and van Vliet, P.: Air pollution from truck traffic and lung function in children living near motorways, Epidemiology, 8, 298-303, 1997.

Canagaratna, M. R., Jayne, J. T., Ghertner, D. A., Herndon, S., Shi, Q., Jimenez, J. L., Silva, P. J., Williams, P., Lanni, T., Drewnick, F., Demerjian, K. L., Kolb, C. E., and Worsnop, D. R.: Chase studies of particulate emissions from in-use New York City vehicles, Aerosol Sci. Tech., 38, 555-573, 2004.

Canagaratna, M. R., Onasch, T. B., Wood, E. C., Herndon, S. C., Jayne, J. T., Cross, E. S., Miake-Lye, R. C., Kolb, C. E., and Worsnop, D. R.: Evolution of vehicle exhaust particles in the atmosphere, J. Air Waste Manage. Assoc., 60, 1192-1203, 2010.

DeCarlo, P. F., Slowik, J. G., Worsnop, D. R., Davidovits, P., and Jimenez, J. L.: Particle morphology and density characterization by combined mobility and aerodynamic diameter measurements, Part 1: Theory, Aerosol Sci. Tech., 38, 1185-1205, 2004.

DeCarlo, P. F., Kimmel, J. R., Trimborn, A., Northway, M. J., Jayne, J. T., Aiken, A. C., Gonin, M., Fuhrer, K., Horvath, T., Docherty, K. S., Worsnop, D. R., and Jimenez, J. L.: Field-Deployable, High-Resolution, Time-of-Flight Aerosol Mass Spectrometer, Anal. Chem., 78, 8281-8289, 2006. 
DeCarlo, P. F., Ulbrich, I. M., Crounse, J., de Foy, B., Dunlea, E. J., Aiken, A. C., Knapp, D., Weinheimer, A. J., Campos, T., Wennberg, P. O., and Jimenez, J. L.: Investigation of the sources and processing of organic aerosol over the Central Mexican Plateau from aircraft measurements during MILAGRO, Atmos. Chem. Phys., 10, 5257-5280, doi:10.5194/acp-10-52572010, 2010.

Drewnick, F., Schwab, J. J., Jayne, J. T., Canagaratna, M., Worsnop, D. R., and Demerjian, K. L.: Measurement of ambient aerosol composition during the PMTACS-NY 2001 using an Aerosol Mass Spectrometer, Part II: Chemically speciated mass distributions, Aerosol Sci. Tech., 38, 104-117, 2004.

Drewnick, F., Hings, S. S., DeCarlo, P. F., Jayne, J. T., Gonin, M., Fuhrer, K., Weimer, S., Jimenez, J. L., Demerjian, K. L., Borrmann, S., and Worsnop, D. R.: A new Time-of-Flight Aerosol Mass Spectrometer (ToF-AMS) - Instrument description and first field deployment., Aerosol Sci. Tech., 39, 637-658, 2005.

Durant, J. L., Ash, C. A., Wood, E. C., Herndon, S. C., Jayne, J. T., Knighton, W. B., Canagaratna, M. R., Trull, J. B., Brugge, D., Zamore, W., and Kolb, C. E.: Short-term variation in nearhighway air pollutant gradients on a winter morning, Atmos. Chem. Phys., 10, 8341-8352, doi:10.5194/acp-10-8341-2010, 2010.

Gillies, J. A., Gertler, A. W., Sagebiel, J. C., and Dippel, W. A.: On-Road Particulate Matter (PM2.5 and PM10) Emissions in the Sepulveda Tunnel, Los Angeles, California, Environ. Sci. Technol., 35, 1054-1063, 10.1021/es991320p, 2001.

Herndon, S. C., Shorter, J. H., Zahniser, M. S., Wormhoudt, J., Nelson, D. D., Demerjian, K. L., and Kolb, C. E.: Real-time measurements of $\mathrm{SO}_{2}, \mathrm{H}_{2} \mathrm{CO}$, and $\mathrm{CH}_{4}$ emissions from in-use curbside passenger buses in New York City using a chase vehicle, Environ. Sci. Technol., 39, 7984-7990, 2005.

Hildebrandt, L., Engelhart, G. J., Mohr, C., Kostenidou, E., Lanz, V. A., Bougiatioti, A., DeCarlo, P. F., Prevot, A. S. H., Baltensperger, U., Mihalopoulos, N., Donahue, N. M., and Pandis, S. N.: Aged organic aerosol in the Eastern Mediterranean: the Finokalia Aerosol Measurement Experiment - 2008, Atmos. Chem. Phys., 10, 4167-4186, doi:10.5194/acp-10-4167-2010, 2010.

Jayne, J. T., Leard, D. C., Zhang, X., Davidovits, P., Smith, K. A., Kolb, C. E., and Worsnop, D. R.: Development of an aerosol mass spectrometer for size and composition analysis of submicron particles, Aerosol Sci. Tech., 33, 49-70, 2000.

Jimenez, J. L., Jayne, J. T., Shi, Q., Kolb, C. E., Worsnop, D. R., Yourshaw, I., Seinfeld, J. H., Flagan, R. C., Zhang, X., Smith, K. A., Morris, J. W., and Davidovits, P.: Ambient aerosol sampling with an Aerosol Mass Spectrometer, J. Geophys. Res.-Atmos., 108, 8425, doi:10:1029/2001JD001213, 2003.

Kirchstetter, T., Harley, R., Kreisberg, N., Stolzenburg, M., and Hering, S.: On-road measurement of fine particle and nitrogen oxide emissions from light- and heavy-duty motor vehicles, Atmos. Environ., 33, 2955-2968, 1999.

Klems, J. P., Pennington, M. R., Zordan, C. A., and Johnston, M. V.: Ultrafine Particles Near a Roadway Intersection: Origin and Apportionment of Fast Changes in Concentration, Environ. Sci. Technol., 44, 7903-7907, doi:10.1021/es102009e, 2010.

Klems, J. P., Pennington, M. R., Zordan, C. A., McFadden, L., and Johnston, M. V.: Apportionment of Motor Vehicle Emissions from Fast Changes in Number Concentration and Chemical
Composition of Ultrafine Particles Near a Roadway Intersection, Environ. Sci. Technol., 45, 5637-5643, doi:10.1021/es104228q, 2011.

Kolb, C. E., Herndon, S. C., McManus, J. B., Shorter, J. H., Zahniser, M. S., Nelson, D. D., Jayne, J. T., Canagaratna, M. R., and Worsnop, D. R.: Mobile Laboratory with Rapid Response Instruments for Real-Time Measurements of Urban and Regional Trace Gas and Particulate Distributions and Emission Source Characteristics, Environ. Sci. Technol., 38, 5694-5703, doi:10.1021/es030718p, 2004.

Lide, D. R.: CRC Handbook of Chemistry and Physics, 73rd ed., CRC Press, Boca Raton FL, 1992.

Lin, Y. C., Schwab, J. J., Demerjian, K. L., Bae, M.-S., Chen, W.N., Sun, Y., Zhang, Q., Hung, H.-M., and Perry, J.: Summertime Formaldehyde Observations in New York City: Ambient levels, Sources and Its Contribution to $\mathrm{HO}_{\mathrm{x}}$ Radicals, J. Geophys. Res., submitted, 2012.

Lindgren, A., Stroh, E., Montnemery, P., Nihlen, U., Jakobsson, K., and Axmon, A.: Traffic-related air pollution associated with prevalence of asthma and COPD/chronic bronchitis. A crosssectional study in Southern Sweden, Int. J. Health Geogr., 8, 2, doi:10.1186/1476-072X-8-2, 2009.

Massoli, P., Fortner, E. C., Canagaratna, M. R., Williams, L. R., Zhang, Q., Sun, Y., Schwab, J. J., Onasch, T. B., Demerjian, K. L., Worsnop, D. R., Kolb, C. E., and Jayne, J. T.: Pollution gradients and chemical characterization of particulate matter from vehicular traffic near major roadways: results from the 2009 Queens College Air Quality study in NYC, Aerosol Sci. Technol., submitted, 2012.

Morawska, L., Ristovski, Z., Jayaratne, E. R., Keogh, D. U., and Ling, X.: Ambient nano and ultrafine particles from motor vehicle emissions: Characteristics, ambient processing and implications on human exposure, Atmos. Environ., 42, 8113-8138, doi:10.1016/j.atmosenv.2008.07.050, 2008.

Ng, N. L., Herndon, S. C., Trimborn, A., Canagaratna, M. R., Croteau, P. L., Onasch, T. B., Sueper, D., Worsnop, D. R., Zhang, Q., Sun, Y. L., and Jayne, J. T.: An Aerosol Chemical Speciation Monitor (ACSM) for Routine Monitoring of the Composition and Mass Concentrations of Ambient Aerosol, Aerosol Sci. Technol., 45, 770-784, 2011.

Ntziachristos, L., Ning, Z., Geller, M. D., Sheesley, R. J., Schauer, J. J., and Sioutas, C.: Fine, ultrafine and nanoparticle trace element compositions near a major freeway with a high heavy-duty diesel fraction, Atmos. Environ., 41, 5684-5696, doi:10.1016/j.atmosenv.2007.02.043, 2007.

Paatero, P. and Tapper, U.: Positive matrix factorization: A nonnegative factor model with optimal utilization of error estimates of data values, Environmetrics, 5, 111-126, 1994.

Park, K., Kittelson, D. B., Zachariah, M. R., and McMurry, P. H.: Measurement of inherent material density of nanoparticle agglomerates, J. Nanopart. Res., 6, 267-272, 2004.

Pope, C. A., Ezzati, M., and Dockery, D. W.: Fine-particulate air pollution and life expectancy in the United States, N. Engl. J. Med., 360, 376-386, doi:10.1056/NEJMsa0805646, 2009.

Rogge, W. F., Hildemann, L. M., Mazurek, M. A., Cass, G. R., and Simoneit, B. R. T.: Sources of fine organic aerosol. 2. Noncatalyst and catalyst-equipped automobiles and heavy-duty diesel trucks, Environ. Sci. Technol., 27, 636-651, 1993.

Roorda-Knape, M. C., Janssen, N. A. H., De Hartog, J. J., Van Vliet, 
P. H. N., Harssema, H., and Brunekreef, B.: Air pollution from traffic in city districts near major motorways, Atmos. Environ., 32, 1921-1930, doi:10.1016/s1352-2310(97)00496-2, 1998.

Seinfeld, J. H. and Pandis, S. N.: Atmospheric chemistry and physics: from air pollution to climate change, Wiley, John \& Sons, Incorporated, New York, 1203 pp., 2006.

Sueper, D.: ToF-AMS Analysis Software online available at: http://cires.colorado.edu/jimenez-group/ToFAMSResources/ ToFSoftware/index.html, last access: 2 June, 2011.

Sun, Y.-L., Zhang, Q., Schwab, J. J., Chen, W. N., Bae, M. S., Lin, Y. C., Hung, H. M., and Demerjian, K. L.: A case study of aerosol processing and evolution in summer in New York City, Atmos. Chem. Phys., 11, 12737-12750, doi:10.5194/acp11-12737-2011, 2011a.

Sun, Y.-L., Zhang, Q., Schwab, J. J., Demerjian, K. L., Chen, W.N., Bae, M.-S., Hung, H.-M., Hogrefe, O., Frank, B., Rattigan, O. V., and Lin, Y.-C.: Characterization of the sources and processes of organic and inorganic aerosols in New York city with a high-resolution time-of-flight aerosol mass apectrometer, Atmos. Chem. Phys., 11, 1581-1602, doi:10.5194/acp-11-15812011, 2011b.

Thornhill, D. A., Williams, A. E., Onasch, T. B., Wood, E., Herndon, S. C., Kolb, C. E., Knighton, W. B., Zavala, M., Molina, L. T., and Marr, L. C.: Application of positive matrix factorization to on-road measurements for source apportionment of diesel- and gasoline-powered vehicle emissions in Mexico City, Atmos. Chem. Phys., 10, 3629-3644, doi:10.5194/acp-10-36292010, 2010.

Turpin, B. J. and Lim, H. J.: Species contributions to $\mathrm{PM}_{2.5}$ mass concentrations: Revisiting common assumptions for estimating organic mass, Aerosol Sci. Tech., 35, 602-610, 2001.

Ulbrich, I. M., Canagaratna, M. R., Zhang, Q., Worsnop, D. R., and Jimenez, J. L.: Interpretation of organic components from Positive Matrix Factorization of aerosol mass spectrometric data, Atmos. Chem. Phys., 9, 2891-2918, doi:10.5194/acp-9-28912009, 2009.

Weimer, S., Drewnick, F., Hogrefe, O., Schwab, J. J., Rhoads, K., Orsini, D., Canagaratna, M., Worsnop, D. R., and Demerjian, K. L.: Size-selective nonrefractory ambient aerosol measurements during the Particulate Matter Technology Assessment and Characterization Study-New York 2004 Winter Intensive in New York City, J. Geophys. Res., 111, D18305, doi:10.1029/2006JD007215, 2006.

Zavala, M., Herndon, S. C., Slott, R. S., Dunlea, E. J., Marr, L. C., Shorter, J. H., Zahniser, M., Knighton, W. B., Rogers, T. M., Kolb, C. E., Molina, L. T., and Molina, M. J.: Characterization of on-road vehicle emissions in the Mexico City Metropolitan Area using a mobile laboratory in chase and fleet average measurement modes during the MCMA-2003 field campaign, Atmos. Chem. Phys., 6, 5129-5142, doi:10.5194/acp-6-5129-2006, 2006.
Zavala, M., Herndon, S. C., Wood, E. C., Jayne, J. T., Nelson, D. D., Trimborn, A. M., Dunlea, E., Knighton, W. B., Mendoza, A., Allen, D. T., Kolb, C. E., Molina, M. J., and Molina, L. T.: Comparison of emissions from on-road sources using a mobile laboratory under various driving and operational sampling modes, Atmos. Chem. Phys., 9, 1-14, doi:10.5194/acp-9-1-2009, 2009.

Zhang, K. M., Wexler, A. S., Zhu, Y. F., Hinds, W. C., and Sioutas, C.: Evolution of particle number distribution near roadways. Part II: the "Road-to-Ambient" process, Atmos. Environ., 38, 66556665, doi:10.1016/j.atmosenv.2004.06.044, 2004.

Zhang, Q., Alfarra, M. R., Worsnop, D. R., Allan, J. D., Coe, H., Canagaratna, M. R., and Jimenez, J. L.: Deconvolution and quantification of hydrocarbon-like and oxygenated organic aerosols based on aerosol mass spectrometry, Environ. Sci. Technol., 39, 4938-4952, doi:4910.1021/es0485681, 2005a.

Zhang, Q., Canagaratna, M. C., Jayne, J. T., Worsnop, D. R., and Jimenez, J. L.: Time and size-resolved chemical composition of submicron particles in Pittsburgh - Implications for aerosol sources and processes, J. Geophys. Res., 110, D07S09, doi:10.1029/2004JD004649, 2005b.

Zhang, Q., Worsnop, D. R., Canagaratna, M. R., and Jimenez, J. L.: Hydrocarbon-like and oxygenated organic aerosols in Pittsburgh: insights into sources and processes of organic aerosols, Atmos. Chem. Phys., 5, 3289-3311, doi:10.5194/acp-5-32892005, 2005 c.

Zhang, Q., Jimenez, J. L., Canagaratna, M. R., Allan, J. D., Coe, H., Ulbrich, I., Alfarra, M. R., Takami, A., Middlebrook, A. M., Sun, Y. L., Dzepina, K., Dunlea, E., Docherty, K., DeCarlo, P. F., Salcedo, D., Onasch, T., Jayne, J. T., Miyoshi, T., Shimono, A., Hatakeyama, S., Takegawa, N., Kondo, Y., Schneider, J., Drewnick, F., Weimer, S., Demerjian, K., Williams, P., Bower, K., Bahreini, R., Cottrell, L., R.J.Griffin, Rautiainen, J., Sun, J. Y., Zhang, Y. M., and Worsnop, D. R.: Ubiquity and dominance of oxygenated species in organic aerosols in anthropogenicallyinfluenced northern hemisphere mid-latitudes, Geophys. Res. Lett., 34, L13801, doi:10.1029/2007GL029979, 2007.

Zhang, Q., Jimenez, J., Canagaratna, M., Ulbrich, I., Ng, N., Worsnop, D., and Sun, Y.: Understanding atmospheric organic aerosols via factor analysis of aerosol mass spectrometry: a review, Anal. Bioanal. Chem., 401, 3045-3067, 10.1007/s00216011-5355-y, 2011.

Zhu, Y., Hinds, W. C., Kim, S., Shen, S., and Sioutas, C.: Study of ultrafine particles near a major highway with heavy-duty diesel traffic, Atmos. Environ., 36, 4323-4335, 2002a.

Zhu, Y., Hinds, W. C., Kim, S., and Sioutas, C.: Concentration and size distribution of ultrafine particles near a major highway, J. Air Waste Manage. Assoc., 52, 1032-1042, 2002b.

Zordan, C. A., Wang, S., and Johnston, M. V.: Time-Resolved Chemical Composition of Individual Nanoparticles in Urban Air, Environ. Sci. Technol., 42, 6631-6636, doi:10.1021/es800880z, 2008. 